\title{
Effect of Dietary Thyroxine on Muscle Protein Metabolism and Abdominal Fat Content in Broiler Chicken in Hot and \\ Moderate Environments
}

\author{
Kunioki Hayashi, Shunichi Kukita, Michiko MukaI, \\ Masaaki ToYomizu* and Yuichiro TOMita \\ Department of Animal Science, Faculty of Agriculture, \\ Kagoshima University, Kagoshima-shi 890
}

(Received December 14, 1988)

\begin{abstract}
The present experiments were undertaken to investigate the effects of dietary thyroxine $(1.2 \mathrm{ppm})$ on the growth, weight of pectoral profundus muscle, rates of muscle protein synthesis and breakdown estimated by $\mathrm{N}^{z}$-methylhistidine method and abdominal fat content in the male intact broiler chicken from 15 to 27 days of age in hot $\left(30^{\circ} \mathrm{C}\right)$ and moderate $\left(25^{\circ} \mathrm{C}\right)$ environments. In the hot environment, dietary thyroxine decreased body weight gain, rate of muscle protein synthesis and abdominal fat content and increased the feed conversion ratio, although pectoral profundus muscle weight and the rate of muscle protein breakdown were not changed. In the moderate environment, dietary thyroxine increased pectoral profundus muscle weight and decreased the feed conversion ratio. However, body weight gain, rates of muscle protein synthesis and breakdown and abdominal fat content did not change significantly. These results indicate that the effects of thyroxine on protein and lipid metabolism in broiler chickens under hot environmental conditions are different from those under moderate environmental conditions.
\end{abstract}

Jpn.J. Zootech. Sci., 61 (12) : 1107-1112, 1990

Key words : thyroxine, muscle growth, abdominal fat, environmental temperature

Thyroid size and thyroid secretion rate are decreased by high environmental temperature and increased by low environmental temperature in the chicken ${ }^{1,2,13}$. The administration of thyroid hormone produces a rise in the basal metabolism, and this is associated with increased oxygen consumption and heat production $^{15,17}$. It is also well known that the thyroid hormone plays important roles in the regulation of protein metabolism ${ }^{18)}$. In a previous study ${ }^{19)}$, we observed that an appropriate amount of dietary thyroxine $(1.2 \mathrm{ppm})$ increased muscle protein synthesis, muscle growth and feed efficiency in intact male broiler chickens in a moderate temperature environment. However, dietary thyroxine may detrimentally influence the growth of broiler chickens at high environmental temperatures due to its thermogenic effects. The present study was undertaken to observe how dietary thyroxine acts on growth, the feed conversion ratio, rates of muscle protein synthesis and breakdown and abdominal fat content under hot and moderate environmental conditions.

* Present address: Department of Animal Science, Faculty of Agriculture, Niigata University, Niigata-shi 950-21 


\section{Materials and Methods}

Two experiments with the same protocol were conducted separately under moderate $\left(25^{\circ} \mathrm{C}\right.$, Experiment 1) and high $\left(30^{\circ} \mathrm{C}\right.$, Experiment 2) environmental temperatures. Seventy male chicks (Arbor Acres), obtained from a commercial hatchery at one day of age, were placed in an electrically-heated brooder until 12 days of age, and were provided with water and a commercial starter diet ad libitum for first 12 days. Twenty-eight birds were selected by body weight, and 2 birds were housed per unit in wire-bottomed aluminum cages $(49 \times 40$ $\times 67 \mathrm{~cm}$ ) when they were 12 days old. The birds were assigned to 2 treatment groups with 7 units per treatment in each experiment. Chicks received preconditioning for 3 days from 12 days of age. Each of two experimental diets (Table 1) containing 0 and $1.2 \mathrm{ppm} \mathrm{L-}$ thyroxine sodium salt (SIGMA Chemical Company, St. Louis, USA) were fed ad libitum throughout the experimental periods from 15 days to 27 days of age. The experiments were conducted in temperature-controlled environments $\left(25 \pm 1\right.$ or $\left.30 \pm 1^{\circ} \mathrm{C}\right)$ with a 14 -hr light and 10 -hr dark cycle.

At the end of the experimental period, the birds were killed by decapitation and dissected, and a pair of pectoral profundus muscles and abdominal fat were weighed. Feed consumption was recorded daily and body weights were determined every 3 days. Since the pectoral profundus muscle is readily dissectible and its lipid content is much lower than that of thigh muscles $10.54 \%$ and $2.51 \%$ for breast muscle and thigh muscle, respectively; T. FukunaGA, unpublished), the muscle weight was selected as a measure of skeletal muscle growth. The growth rate of breast muscle is parallel to that of thigh muscle in the stage of growth between 2 and 4 weeks of age ${ }^{14)}$.

Excreta samples were collected daily for 3 days from 24 days of age and pooled to measure rate muscle protein synthesis and
Table 1. Composition of experimental diet

\begin{tabular}{lc}
\hline Ingredients & $(\%)$ \\
\hline Ground yellow corn & 76.00 \\
Purified soybean protein & 15.96 \\
Dehydrated alfalfa meal & 4.00 \\
Mineral mixture & 11 \\
Vitamin mixture & 3.31 \\
Choline chloride & 0.06 \\
L-Lysine & 0.07 \\
DL-Methionine & 0.28 \\
\hline Crude protein & 0.32 \\
Metabolizable energy (kcal/kg) & 20.0 \\
\hline
\end{tabular}

"Contained $(\mathrm{g} / \mathrm{kg})$ : celcium carbonate, 210.8; calcium hydrogen phosphate, 660.2 ; sodium chloride, 112.4; manganese sulfate, 6.6 ; zinc sulfate, 3.9 ; ferrous sulfate, 5.85 ; cupric sulfate, 0.228 ; sodium iodate, 0.016 ; selenious acid, 0.006 .

2) Containing $11,650,000$ IU vitamin $A ; 2,330,000 \mathrm{IU}$ vitamin $\mathrm{D} ; 1.2 \mathrm{~g}$ vitamin $\mathrm{E} ; 10.1 \mathrm{~g}$ ribollabin; $0.97 \mathrm{~g}$ vitamin $\mathrm{B} ; 0.02 \mathrm{~g}$ cyanocobalamin; $4.2 \mathrm{~g}$ pantothenyl alcohol; $23.7 \mathrm{~g}$ nicotinic acid; $0.9 \mathrm{~g}$ vitamin $\mathrm{K} ; 0.8 \mathrm{~g}$ folic acid; $48.6 \mathrm{~g}$ choline chloride and $0.6 \mathrm{~g}$ biotin per $\mathrm{kg}$.

breakdown by the $\mathrm{N}^{\tau}$-methylhistidine $\left(\mathrm{N}^{\top}-\mathrm{MH}\right)$ $\operatorname{method}^{7,8,20)}$ as mentioned in the previous report ${ }^{9)}$. $\quad \mathrm{N}^{\tau}-\mathrm{MH}$ was determined by the method of HAYASHI et al. ${ }^{10)}$. The outline of the procedure is as follows. The whole excreta sample was homogenized with $100 \mathrm{~m} l$ water, and $2 \mathrm{~g}$ of the homogenate was hydrolyzed with $6 \mathrm{~N} \mathrm{HCl}$ at $115^{\circ} \mathrm{C}$ for $24 \mathrm{hr}$. After the hydrolysate was cooled and filtered through filter paper, the volume was adjusted to $25 \mathrm{~m} l$ with water. Using $10 \mathrm{ml}$ of the hydrolysate, hydrochloric acid was removed by evaporation. The residue was dissolved in $15 \mathrm{ml}$.of $0.2 \mathrm{M}$ pyridine, and $3 \mathrm{~m} l$ of this was applied to an anion-exchange resin column $(7 \times 60 \mathrm{~mm}$, Dowex $50 \times 8,200-$ 400 mesh, pyridine form). After eluting most of the acid and neutral amino acids with $20 \mathrm{ml}$ of $0.2 \mathrm{M}$ pyridine, $\mathrm{N}^{\tau}-\mathrm{MH}$ was eluted with $20 \mathrm{ml}$ of $1 \mathrm{M}$ pyridine and collected. The eluent was then dried, and the residue was dissolved in $1 \mathrm{~m} l$ of the mobile phase $(15 \mathrm{mM}$ sodium octane sulfonate in $20 \mathrm{mM} \mathrm{KH_{2 }} \mathrm{PO}_{4}$ ) and $50 \mu l$ of this was used for the HPLC analysis that utilizes a reversed-phase separation with ion-pairing using a Zorbax ODS 
column $(4.6 \times 150 \mathrm{~mm})$ and post-column fluorescence derivatization using orthophthalaldehyde.

The fractional rate of muscle protein breakdown (Kd) and synthesis (Ks) were then calculated as follows. Skeletal muscle comprises $29.3 \%$ of the live weight in the 4 -weekold broiler chicken, and $\mathrm{N}^{\tau}-\mathrm{MH}$ concentration of the muscle was $0.606 \mu \mathrm{mol} / \mathrm{g}^{16)}$. Thus, the pool size of $\mathrm{N}^{\tau}-\mathrm{MH}$ in the skeletal muscle was estimated to be $17.4 \mu \mathrm{mol} / 100 \mathrm{~g}$ body weight. Since the diet contained $\mathrm{N}^{\mathrm{T}}-\mathrm{MH}(0.040 \mu \mathrm{mol} /$ $g$ ), it was subtracted from total excreted $\mathrm{N}^{\tau_{-}}$ $\mathrm{MH}$ in order to estimate $\mathrm{N}^{2}-\mathrm{MH}$ derived from body tissues. This was multiplied by 0.8 to give the excreted $\mathrm{N}^{t}-\mathrm{MH}$ derived from skeletal muscle as reported previously ${ }^{9)}$.

The fractional breakdown rate was calculated by dividing the amount of excreted $\mathrm{N}^{{ }-\mathrm{MH}}$ derived from skeletal muscle by the amount of
$\mathrm{N}^{2}-\mathrm{MH}$ in the skeletal muscle. The fractional rate of muscle protein synthesis was calculated by the mathematical model described by FUnABIKI et al. ${ }^{7}$.

The mean value of the two birds housed in the same cage was treated as a single datum, and the significance of difference between groups was assessed via the Student's t test.

\section{Results}

The present experiments were conducted separately, but the results are shown together in Table 2.

Under moderate conditions $\left(25^{\circ} \mathrm{C}\right.$, Experiment. 1), dietary thyroxine had no significant effects on feed consumption, body weight gain and abdominal fat content. However, dietary thyroxine decreased the feed conversion ratio and increased pectoral profundus muscle weight significantly. The amount of $\mathrm{N}^{\tau}-\mathrm{MH}$ in the

Table 2. Effects of dietary thyroxine on body weight gain, feed conversion ratio, pectoral profundus muscle weight, abdominal fat content and rates of muscle protein synthesis (Ks) and breakdown (Kd.) estimated by $\mathrm{N}^{\mathrm{r}}$-methylhistidine $\left(\mathrm{N}^{\mathrm{r}}-\mathrm{MH}\right)$ method

\begin{tabular}{|c|c|c|c|c|}
\hline & \multicolumn{2}{|c|}{$\begin{array}{c}\text { Experiment } 1 \\
\left(25^{\circ} \mathrm{C} \text { environment }\right)\end{array}$} & \multicolumn{2}{|c|}{$\begin{array}{c}\text { Experiment } 2 \\
\left(30^{\circ} \mathrm{C} \text { environment }\right)\end{array}$} \\
\hline & Control & Thyroxine & Control & Thyroxine \\
\hline Initial body weight & $315 \pm 17$ & $314 \pm 19$ & $303 \pm 5$ & $305 \pm 6$ \\
\hline $\begin{array}{l}\text { Body weight gain } \\
(\mathrm{g} / 12 \text { days })\end{array}$ & $362 \pm 74$ & $400 \pm 47$ & $417 \pm 30$ & $386 \pm 19 *$ \\
\hline $\begin{array}{l}\text { Feed consumption } \\
(\mathrm{g} / 12 \text { days })\end{array}$ & $647 \pm 84$ & $681 \pm 64$ & $734 \pm 54$ & $737 \pm 50$ \\
\hline $\begin{array}{l}\text { Feed conversion } \\
\text { ratio }\end{array}$ & $1.82 \pm 0.16$ & $1.67 \pm 0.07^{*}$ & $1.77 \pm 0.14$ & $1.92 \pm 0.14^{*}$ \\
\hline $\begin{array}{l}\text { Pectoral profundus } \\
\text { muscle weight }(\mathrm{g})\end{array}$ & $16.9 \pm 1.2$ & $19.0 \pm 1.5^{*}$ & $17.3 \pm 1.3$ & $17.1 \pm 1.3$ \\
\hline $\begin{array}{l}\text { Abdominal fat } \\
\text { content }(g)\end{array}$ & $4.37 \pm 2.5$ & $3.84 \pm 1.1$ & $7.01 \pm 1.5$ & $3.91 \pm 1.8^{*}$ \\
\hline $\begin{array}{l}\text { Total skeletal } \\
\text { muscle } \mathrm{N}^{\mathrm{r}}-\mathrm{MH} \text { content } \\
(\mu \mathrm{mol})\end{array}$ & $118 \pm 15$ & $123 \pm 12$ & $125 \pm 6$ & $120 \pm 4$ \\
\hline$\underset{(\mu \text { mol/day })}{\text { Total excreted } N^{r}-M H}$ & $8.26 \pm 1.44$ & $9.42 \pm 1.88$ & $3.83 \pm 0.95$ & $2.96 \pm 0.49^{*}$ \\
\hline $\begin{array}{l}\mathrm{N}^{*}-\mathrm{MH} \text { derived from } \\
\text { feed }(\mu \mathrm{mol} / \mathrm{d} \mathrm{y})\end{array}$ & $2.54 \pm 0.42$ & $2.64 \pm 0.30$ & $2.45 \pm 0.18$ & $2.46 \pm 0.17$ \\
\hline $\begin{array}{l}\mathrm{N}^{5}-\mathrm{MH} \text { derived from. } \\
\text { skeletal muscle } \\
\quad(\mu \mathrm{mol} / \mathrm{day})\end{array}$ & $4.57 \pm 0.97$ & $5.41 \pm 1.47$ & $1.10 \pm 0.75$ & $0.40 \pm 0.53^{*}$ \\
\hline $\mathrm{Kd}(\mathscr{6} /$ day $)$ & $3.88 \pm 0.82$ & $4.41 \pm 1.14$ & $0.88 \pm 0.58$ & $0.34 \pm 0.45$ \\
\hline $\mathrm{Ks}(\mathscr{6} / \mathrm{day})$ & $10.8 \pm 1.5$ & $11.7 \pm 1.5$ & $6.26 \pm 0.80$ & $5.06 \pm 0.67^{*}$ \\
\hline
\end{tabular}

"Values are mean \pm standard deviations of 7 observations, and means bearing * is significantly $(p<0.05)$ different from respective control group. 
excreta derived from skeletal muscle and the rates of muscle protein synthesis and breakdown tended to increase via the thyroxine treatment.

Under hot conditions $\left(30^{\circ} \mathrm{C}\right.$, Experiment 2), the birds panted, and the effects were different from those at moderate temperature. Body weight gain and abdominal fat content decreased and the feed conversion ratio increased significantly by dietary thyroxine, but feed consumption and pectoral profundus muscle weight were not changed. $\mathrm{N}^{z}-\mathrm{MH}$ excretion derived from skeletal muscle and both the rates of muscle protein synthesis and breakdown were very low, and they were further decreased by dietary thyroxine.

\section{Discussion}

The results of Experiment 1 were consistent with our previous results ${ }^{19)}$ showing that dietary thyroxine $(1.2 \mathrm{ppm})$ increased muscle protein synthesis, muscle weight and feed efficiency in the male broilar chicken under a moderate temperature $\left(25^{\circ} \mathrm{C}\right)$. Although it is well documented that thyroid hormones restore muscle protein synthesis in thyroidectomized or hypophysectomized animals, little is known on the effect of thyroid hormone administration on the rates of muscle protein synthesis and breakdown in intact animals. It is generally thought that the use of thyroactive substances has little advantage in the production of meat animals since thyroid hormones usually function as catabolic agents in intact animals despite the fact that the body fat can be successfully reduced by those substances ${ }^{21)}$. In the previous investigation ${ }^{19}$, it was demonstrated that the performances of broiler chickens were improved by an appropriate amount of thyroxine. It was also suggested that the beneficial effects of dietary thyroxine might be mostly accounted for by the actions of thyroid hormone on muscle protein synthesis and body fat synthesis.

However, in the hot environment $\left(30^{\circ} \mathrm{C}\right)$, the effects of dietary thyroxine were different from those under moderate conditions. Both the rates of muscle protein synthesis and breakdown were lower in the hot environment than those in the moderate environment. This is consistent with the results of our previous investigation $^{11)}$; rates of muscle protein synthesis and breakdown were $6.7 \pm 1.1 \% /$ day and $1.3 \pm 1.1 \% /$ day $(\mathrm{n}=6)$, respectively, in a $30^{\circ} \mathrm{C}$ environment. The changes in the rate of muscle protein turnover might have an important physiological meaning since protein synthesis is responsible for $15-40 \%$ of total heat production of growing animals at moderate temperature ${ }^{3,6)}$, and protein breakdown also contributes to heat production. Thus, the regulation of protein synthesis and breakdown in the skeletal muscle which is the largest organ in the body probably have a role in controlling body temperature.

It should be also noted that dietary thyroxine decreased the rates of muscle protein synthesis and breakdown under high temperature condition since thyroxine had been believed to stimulate both the rates of protein synthesis and breakdown ${ }^{4,5)}$. The present results may show that the effect of the thyroid hormone on muscle protein metabolism is different in birds under hot environmental conditions from those under moderate environmental conditions. The difference of thyroid hormone action due to environmental temperature is interesting but difficult to explain.

It is well documented that abdominal fat content is higher in the hot environment than in the moderate environment ${ }^{12}$. Abdominal fat decreased significantly by dietary thyroxine in the hot environment, but not in the moderate environment in the present experiments. This can be explained as follows : abdominal fat content was increased by high environmental temperature $\left(30^{\circ} \mathrm{C}\right)$ because thyroid function was decreased, and it was decreased to the normal level by dietary thyroxine. This seems to be the reason why 


\section{Effect of Thyroxine in Hot Environment}

body weight gain decreased and the feed conversion ratio increased via dietary thyroxine in the hot environment. Dietary thyroxine (1.2 ppm) might increase heat loss and decrease lipogenesis in the hot environment, and thus feed conversion ratio was increased and abdominal fat content was decreased by the thyroxine treatment, but not in the moderate environment. In the previous study ${ }^{19)}$, the feed conversion ratio was decreased and abdominal fat content remained the same via the same level of dietary thyroxine, implying that this level of thyroxine neither increases heat loss nor decreases lipogenesis in male broiler chickens at moderate temperatures.

The metabolism of thyroid hormone is possibly influenced by environmental temperature. However, we think that this is less probable because changes in the thyroid weights due to dietary thyroxine were similar in the present two experiments. The thyroid weights $(\mathrm{g} / 100 \mathrm{~g} \mathrm{B.W}$ ) were $5.5 \pm 1.3$ (Control), $2.1 \pm 0.7$ (Treatment) and $8.3 \pm 1.8$ (Control), $4.0 \pm 1.4$ (Treatment) in the hot and moderate temperature environments, respectively.

The present investigation indicates that thyroxine acts differently on protein and lipid metabolisms in broiler chickens under hot and moderate environmental conditions. However, further experiments are necessary to confirm these findings. The original purpose of this study was to know how dietary thyroxine affects the productivity of broiler chickens in a hot environment. Although the present results are not directly applicable to broiler production, it is possible to decrease body fat content without decreasing muscle mass by dietary thyroxine in a hot environment.

\section{References}

1) AKiba, Y., K. Takahashi, M. Kimura, S.I. Hirama and T. Matsumoto, The influence of environmental temperature, thyroid status and a synthetic oestrogen on the induction of fatty livers in chicks. $\mathrm{Br}$. Poult. Sci, $24: 71-80.1983$.

2) de Andrade, A.N., J.C. Rogler, W.R. Featherston and C.W. Alliston, Interrelationships between diet and elevated temperatures (cyclic and constant) on egg production and shell quality. Poult. Sci., 56 : 11781188. 1977.

3) Bernier, J.F., C.C. Calvent and R.L. Baldwin, Energetics of protein synthesis in mice with a major gene for growth. J. Nutr. $117: 2036-2045.1987$.

4) Brown, J.G., P.C. Bates, M.A. Holliday and D.J. MILLWARD, Thyroid hormones and muscle protein turnover: The effect of thyroid-hormone deficiency and replacement in thyroidectomized and hypophysectomized rats. Biochem. J., 194: 771-782. 1981.

5) Carter, W.J., W.S.W. BenJamin and F.H. FAas, Effect of experimental hyperthyroidism on skeletalmuscle proteolysis. Biochem. J., $194: 685-690.1981$.

6) DAvis, S.R., T.N. BARKY and G.A. HUGHSON, Protein synthesis in tissues of growing lambs. Br. J. Nutr, 46 : 409-419. 1981.

7) Funabiki, R., Y. Watanabe, N. Nishizawa and S. HAREYAMA, Quantitative aspect of the myofibrillar protein turnover in transient state on dietary protein depletion and repletion revealed by urinary excretion of $\mathrm{N}^{t}$-methylhistidine. Biochem. Biophys. Acta, 451 : 143-150. 1976.

8) Harris, C.I., G. Milne and R. Mcdiarmid, The retention and metabolism of $\mathrm{N}^{T}$-methylhistidine by cockerels : implications for the measurement of muscle protein breakdown determined from the excretion of $\mathrm{N}^{2}$..methylhistidine in excreta. Br. J. Nutr., $57: 467-$ 478. 1987.

9) Hayashi, K., Y. Tomita, Y. Maeda, Y. Shinagawa, K. InOUe and T. HAShizume, The rate of degradation of myofibrillar proteins of skeletal muscle in broiler and layer chickens estimated by $\mathrm{N}^{T}$-methylhistidine in excreta. Br. J. Nutr., 54: 157-163. 1985.

10) Hayashi, K., Y. Maeda, M. ToYomizu and Y. ToMITA, High-performance liquid chromatographic method for the analysis of $\mathrm{N}^{\tau}$-methylhistidine in food, chicken excreta, and rat urine. J. Nutr. Sci. Vitaminol., 33 : 151-156. 1987.

11) Hayashi, K., M. Nakano, M. ToyomizU, Y. Tomita, T. IWAMoro and A. SHIKA, Effect of fasting early in life on performance, mortality and muscle protein metabolism of broiler chicken in high temperature environment. Jpn. J. Zootech. Sci., 61 : 264-270. 1990.

12) Howlider, M.A.R. and S.P. Rose, Temperature and the growth of broilers. World's Poult. Sci. J., $43: 228-$ 237. 1987.

13) Huston, T.M., H.N. Edwards and J.J. Williams, The effects of high environmental temperature on thyroid secretion rate of domestic fowl. Poult. Sci., 41 : 640-646. 1962.

14) Kang, C.W., M.L. Sunde and R.W. Swick, Growth and protein turnover in the skeletal muscles of broiler chicks. Poult. Sci., 64 : 370-379. 1985.

15) Kittok, R.J., T.J. Greninger, J.A. Desshazer, S.R. LowARY and F.B. Mather. Metabolic response of the rooster after exogenous thyroid hormones. 


\section{Hayashi, Kukita, Mukai, Toyomizu and Tomita}

Poult. Sci., 61 : 1748-1752. 1982.

16) MaEda, Y, K. HaYashi, S. TOYohara and T. HASHIGUCHI, Variation among chicken stocks in the fractional rates of muscle protein synthesis and degradation. Biochem. Genet., 22 : 687-700. 1984.

17) Muramatsu, T., J.H. Bo, J. OKumura and I. TASAK1, Effect of tri-iodothyronine administration on heat production in young chicks. Jpn, J. Zootech. Sci., 57 : 946-956. 1986.

18) Spencer, G.S.G., Hormonal systems regulating growth. A review. Livest. Prod. Sci., $12: 31-46.1985$.

19) Suthama, N., K. Hayashi, M. Toyomizu and Y.
TOMITA. Effect of dietary thyroxine on growth and muscle protein metabolism in broiler chickens. Poult. Sci., 68: 1396-1401. 1989.

20) Tomas, F.M., L.M. Jones and R.A. PyM, Rates of muscle protein breakdown in chickens selected for increased growth rate, food consumption or efficiency of food utilisation as assessed by $\mathrm{N}^{\tau}$-methylhistidine excretion. Br. Poult. Sci., 29 : 359-370. 1988.

21) Wilson, H.R., M.A. Boone, A.S. ARAFa and D.M. JANKY, Abdominal fat pad in broilers with thyroactive iodinated casein. Poult. Sci., $62: 811-818.1983$.

\section{高温ならびに適温環境におけるブロイラーの \\ 筋肉蛋白質代謝および腹腔脂肪量に対する \\ 甲状腺ホルモン投与の影響}

\section{林 國興・久木田春一・向井倫子・豊水正昭・富田裕一郎 \\ 鹿児島大学農学部，鹿児島市 890}

12 日齢のブロイラーヒナ（雄）を，後述の温度環境下，試験飼料により，3 日間予備飼育した後，2 区に分け，試験区にはサイロキシンナトリゥム添加 $(1.2 \mathrm{ppm})$ 飼料を給与し，12 日間飼育した．飼 育室の温度は，夷験 1 では， $25 \pm 1^{\circ} \mathrm{C}$, 実験 2 では $30 \pm 1^{\circ} \mathrm{C}$ とした，その結果， $25^{\circ} \mathrm{C}$ の環境では，增体 量上筋肉蛋白質の合成（Ks）および分解速度（Kd）は堌加の傾向を示し，筋肉（深胸筋）重量は増加， 飼料要求率は低下し，腹腔脂肪量は減少の傾向を示した。一方， $30^{\circ} \mathrm{C}$ の環境では，サイロキシンナト リウム添加により，增体量，腹望脂肪量および $\mathrm{Ks}$ は低下，Kd は低下の攧向を示し，飼料要求乘は上 昇したが、筋肉重量は変化しなかった。また， $30^{\circ} \mathrm{C}$ の環境では， $25^{\circ} \mathrm{C}$ の環境に比べ，腹腔脂肪は多く， $\mathrm{Ks}$ 抢よび Kd は著しく低い值を示した，以上の結果は，高温環境ではサイロキシンの作用が適温環境 下と異なることを示唆している。

日畜会報，61（12）：1107-1112，1990 